\title{
GROWTH PATTERNS AND SPATIAL DISTRIBUTION OF COMMON ASH (FRAXINUS EXCELSIOR L.) IN LATVIA
}

\author{
Kaspars Liepiṇs" ${ }^{\#}$, Jānis Liepiṇš, and Roberts Matisons \\ Latvian State Forest Research Institute "Silava", Rīgas iela 111, Salaspils, LV-2169, LATVIA; \\ kaspars.liepins@silava.Iv \\ \# Corresponding author
}

Communicated by Āris Jansons

\begin{abstract}
In Latvia, common ash (Fraxinus excelsior L.) can form ecologically stable monoculture stands in localities with optimum growing conditions, but they are mainly found in mixed forests throughout the country on sites with fresh, fertile, sufficiently moist, yet well-drained soils. Over the last two decades, ash decline has become a serious problem for the whole of Europe; the causal agent for it is also present in Latvia. The aim of the given study was to investigate the growth patterns of ash in different populations at the age of maturity (over 80 years), tracing back their course of growth, and identify the spatial distribution of ash to identify localities with appreciable concentration of ash-dominated stands. The study revealed high variation in the juvenile growth of ash, and confirmed that the height and diameter growth for common ash peaks at an early age. Analysis of the spatial distribution of ash indicated considerable expansion of common ash over the country during the second half of the $20^{\text {th }}$ century, to some extent complementing natural overgrowing of abandoned lands by forest. Apart from the Zemgale Plain in the middle of Latvia, the highest concentration of ash stands is in upland areas with highly varying land relief conditions.
\end{abstract}

Key words: increments, height-age curves, tree species distribution.

\section{INTRODUCTION}

Common ash (Fraxinus excelsior L.), one of the northern temperate zone hard-wooded broadleaved species, is known to produce valuable timber over relatively short rotations (Kerr, 1995). Because of mechanical properties and ornamental features of its timber comparable to oak, except for low natural resistance to decay (Hannouz et al., 2015), ash wood is widely used in joinery and for flooring (Sakss, 1958; Knaggs and Xenopoulou, 2004). The ecological role of ash in forest ecosystems is also noteworthy due to its association with numerous mammals, bird, bryophyte, fungi, invertebrate and lichen species (Mitchell et al., 2014).

In Europe, the geographic range of common ash extends in the west-east direction from the Atlantic coast almost to the river Volga in inland Russia. Its northern limit is in Norway at $64^{\circ} \mathrm{N}$, extending South to the Mediterranean through the northern regions of Spain, Italy, and Greece as far as $37^{\circ} \mathrm{N}$ in Iran (Anonymous, 2005). Although common ash occurs in a number of forest types and forest communities (Dobrowolska et al., 2011), it grows best in nutrient rich, moist, and yet well-drained soils (Wardle, 1961; Kerr and Cahalan, 2004; Weber-Blaschke et al., 2008).

In Latvia, common ash, although capable of forming ecologically stable monocultures in localities with optimum growing conditions, it is an admixture species found throughout the country in mixed forests along with other broadleaved trees and Norway spruce. Total area of ashdominated stands is 13600 ha and its share in roundwood resources is less than one percent of the total standing volume, and hence its economic importance is negligible for Latvia (Anonymous, 2015). Therefore, Latvian researchers have given little attention to common ash. The preceding studies on the ecological preconditions for successful regeneration of ash and management practices for producing quality timber date back to the mid-20th century (Sakss, 1952).

The decline of ash, over the last two decades, has become a serious problem for Europe as a whole, with the causal agent for it (the pathogenic fungus Hymenoscyphus pseudoalbidus (anamorph Chalara fraxinea) (McKinney et al., 2014)) first appearing in Poland in the 1990s and subsequently infecting ash stands all over the continent (Pautasso et al., 2013). This fungus has also been identified in Latvia (Kenigsvalde et al., 2010). As a result, the cultivation of ash as a forest crop should be discontinued in hope of breeding Chalara fraxinea-resistant genotypes in the future (Cleary et al., 2013; Gross et al., 2014). This rapidly spreading lethal disease, unprecedentedly damaging common ash, spotlights the need for more in-depth studies on the ecology and 
growth patterns of this species, taking into account the broad spatial distribution of common ash populations. The present study will contribute to the identification of the regional populations and exploration of the diversity of ecotypes of the species, which is highly required for elaborating ash protection measures for particular forest growing conditions.

Most of the studies on the growth characteristics of common ash conducted so far in Europe have been carried out within or close to the middle part of the natural range of ash. It would be of interest to investigate the growth features of ash in Latvia, which is close to the northern boundary of its geographical range. The marginal populations of any species are of special interest for species self-survival, as they comprise genetic traits of a population required for adaptation to environmental change (Rajora and Mosseler, 2001).

The aim of the present study was to investigate the past growth patterns of mature ash trees for a number of Latvia's common ash populations at the age of maturity, and to describe the spatial distribution of ash to identify the regions with concentrations of ash-dominated stands. In order to define the geographical distribution of common ash, EUFORGEN recommends that the survey should be undertaken in countries where common ash occurs (Pliûra and Heuertz, 2003). The research results on growth features of common ash will also be useful for evaluating the adequacy of the existing yield tables for predicting the growth and yield of ash and provide new knowledge about the growth patterns of ash.

\section{MATERIAL AND METHODS}

The material for studying the growth patterns of common ash comprises three sample trees in each of four ash-dominated stands in the central and eastern part of Latvia. The study sites selected represent the common ash populations as distinguished by Sakss (1958), who mapped the regions where ash is common as an admixtures species (Fig. 1). According to Latvian forest typology (Zālītis and Jansons, 2013) the sites were classified as Aegopodiosa (Viesīte and Rundāle), and Mercurialosa mel. (Ainaži and Barkava), which represent the typical site conditions for common ash stands. All stands were dominated by common ash with an admixture of other deciduous tree species - wych elm (Ulmus glabra Huds.), black alder (Alnus glutinosa L.), Norway maple (Acer platanoides L.), birch (Betula pendula Roth and Betula pubescens Ehrh.) and common aspen (Populus tremula L.).

As the growth of the dominant trees is minimally affected by competition during the development phase of the stand, in each site three dominant trees with distinctly pronounced apical dominance were selected as sample trees and felled. The height of each sample tree was determined by measuring stem length after felling. The stems were then cut in two-meter sections. All the trees felled showed signs of dieback - dead branches and tops. In determining the stem length, accuracy of 0.1 meter was accepted, as exact measurements were not possible due to loss of tree tops during felling. Cross-sectional discs were sawn off at stump height, 1.3 meters above the stump height (DBH), and at the ends of every stem section. The discs were sanded and scanned at 1200 dpi resolution. The disc basal area and the tree ring widths were measured along four radii using WinDENDRO Reg 2009b software (Regent Instruments Inc. Canada). The biological age of each sample tree was determined by the number of tree rings at stump height. The DBH o.b. was determined from two perpendicular diameters of the discs taken at height 1.3 meters above stump height. The characteristics of sample trees are given in Table 1 .

The stem analysis was conducted using WinSTEM 2005a software (Regent Instruments Inc. Canada). The increment values for tree height, DBH, stem volume, and basal area were averaged for 10-year age brackets. The height-age

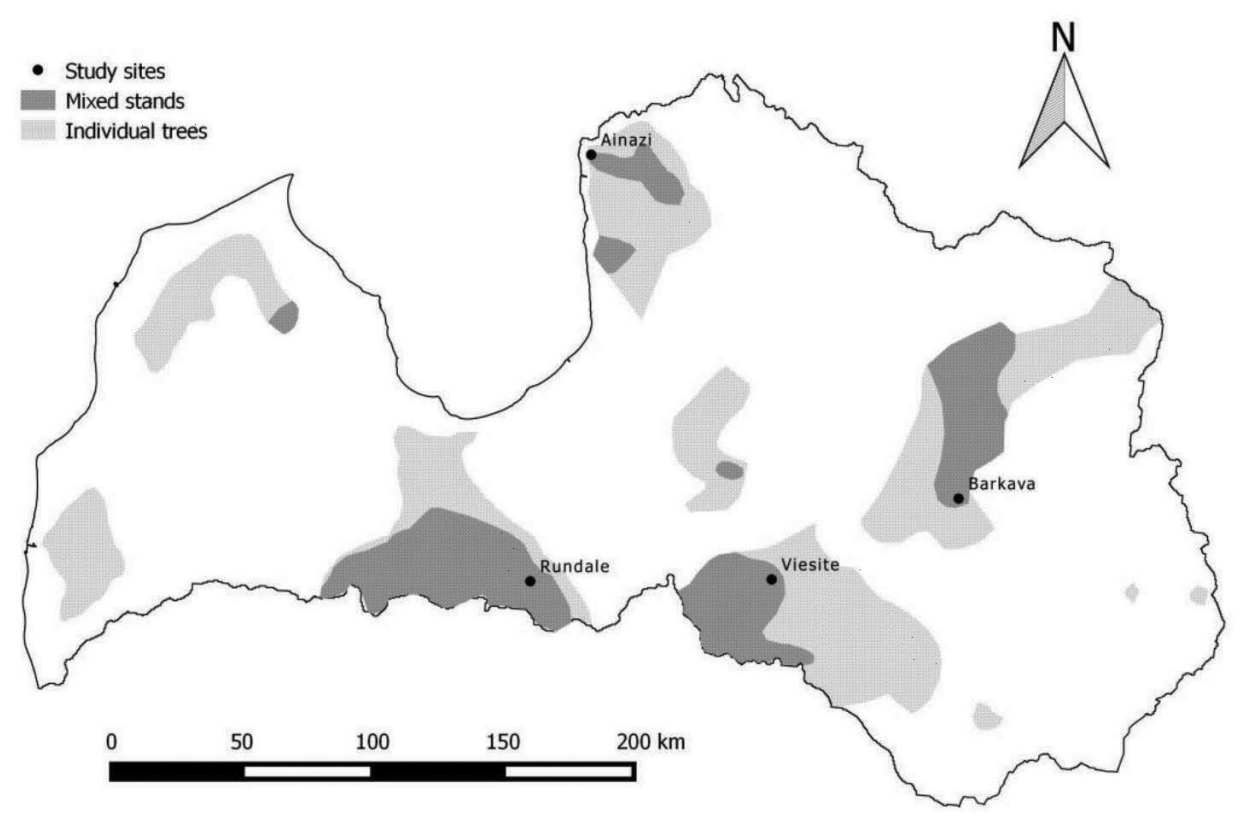

Fig. 1. Spatial distribution of common ash in Latvia determined by Sakss (1958); indicated are the sites where sample trees were taken. 
SAMPLE TREE CHARACTERISTICS

\begin{tabular}{c|c|c|c|c}
\hline $\begin{array}{c}\text { Sample } \\
\text { tree }\end{array}$ & Site & Age, years & DBH, cm & Height, m \\
\hline 1 & Viesīte & 103 & 32 & 27.4 \\
2 & Viesīte & 100 & 46 & 31.4 \\
3 & Viesīte & 102 & 33 & 26.8 \\
4 & Rundāle & 98 & 38 & 25.3 \\
5 & Rundāle & 96 & 30 & 21.9 \\
6 & Rundāle & 101 & 35 & 22.5 \\
7 & Ainaži & 119 & 37 & 24.5 \\
8 & Ainaži & 118 & 44 & 24.4 \\
9 & Ainaži & 120 & 46 & 24.75 \\
10 & Barkava & 85 & 32 & 26.1 \\
11 & Barkava & 83 & 32 & 26 \\
12 & Barkava & 81 & 29 & 26.5
\end{tabular}

curves were modelled following the Chapman-Richards three-parameter growth function, which is widely used for modelling tree and stand growth (e.g. Lekwadi et al., 2012):

$Y=a \times\left(1-E X P(b \times A)^{C}\right.$

where $\mathrm{Y}=$ tree height $(\mathrm{m}) ; \mathrm{A}=$ tree age (years); $\mathrm{a}, \mathrm{b}, \mathrm{c}=$ parameters.

The function parameters were determined using the SYSTAT nonlinear regression procedure for Windows 13 software (Systat Software, Inc. San Jose, USA) by the least squares method and Gauss-Newton algorithm. Goodness of fit of the model was evaluated using the predicted $R_{2}$ values (observed vs. predicted).

To analyse the territorial distribution of common ash in Latvia, data for 2015 from the State Forest Register were used. All stands were selected where common ash was the dominant species with the proportion of ash $\geq 80 \%$ of the total standing volume. The structure of the available databases was not suitable for the identification of the forest stands dominated by other species while containing common ash as an admixture species. For this reason, such forest stands were not included in the analyses. QGIS version 2.8.3 software (Free Software Foundation, Inc., Boston, USA) was used for plotting the data on the map.

\section{RESULTS}

The Chapman-Richards sigmoid growth function (1) used here quite adequately describes the growth of the studied ash trees: the values of the coefficients calculated for the growth function equations for the four study sites ranged from 0.920 to 0.997 . The estimated coefficients for Eq. 1 are shown in Table 2.

The growth of ash trees in height in the two eastern sites (Viesite and Barkava) was similar, with the growth patterns in the two other sites differing (Fig. 2). At the age of 100 years the tree height at Rundāle and Ainaži was similar:
ESTIMATED PARAMETERS FOR MODELLING HEIGHT-AGE CURVES FOR TREE GROWTH IN THE STUDY SITES

\begin{tabular}{c|c|c|c|c|c}
\hline $\begin{array}{c}\text { Parame- } \\
\text { ter }\end{array}$ & Estimate & SE & $\begin{array}{c}\text { Parame- } \\
\text { ter/SE }\end{array}$ & \multicolumn{2}{|c}{$\begin{array}{c}\text { Wald 95\% Confidence } \\
\text { interval }\end{array}$} \\
\cline { 5 - 6 } & & & & Lower & Upper \\
\hline Viesīte & & & & & \\
a & 30.616 & 0.353 & 86.796 & 29.922 & 31.31 \\
b & -0.034 & 0.002 & -22.018 & -0.037 & -0.031 \\
c & 1.657 & 0.074 & 22.441 & 1.512 & 1.803 \\
Rundāle & & & & & \\
a & 26.426 & 0.881 & 30.01 & 24.693 & 28.159 \\
b & -0.027 & 0.003 & -8.865 & -0.033 & -0.021 \\
c & 1.332 & 0.112 & 11.869 & 1.112 & 1.553 \\
Ainaži & & & & & \\
a & 25.34 & 0.061 & 413.88 & 25.22 & 25.461 \\
b & -0.031 & 0 & -71.641 & -0.032 & -0.03 \\
c & 0.99 & 0.012 & 84.863 & 0.967 & 1.013 \\
Barkava & & & & & \\
a & 29.757 & 0.419 & 71.032 & 28.932 & 30.582 \\
b & -0.031 & 0.001 & -21.358 & -0.034 & -0.028 \\
c & 1.348 & 0.047 & 28.691 & 1.256 & 1.441 \\
& & & & &
\end{tabular}

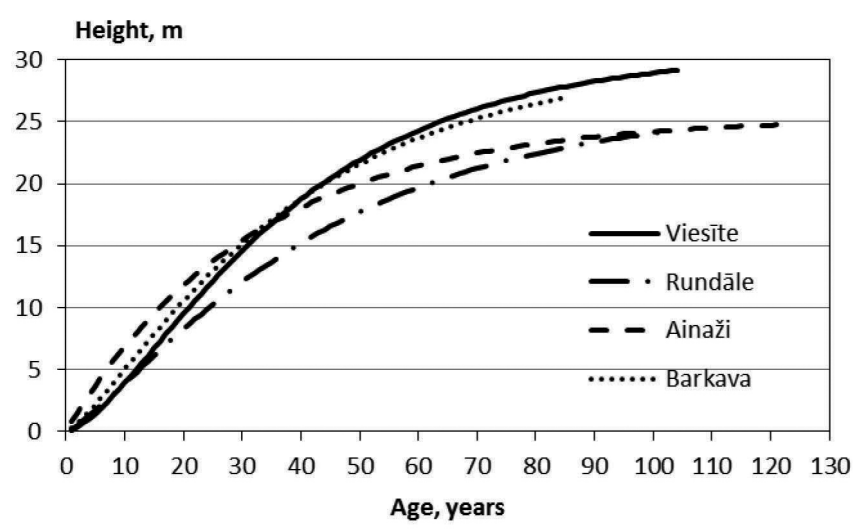

Fig. 2. Modelled height-age curves.

slightly below 25 meters. The development of height-age curves in younger age stages markedly differed for both sites. At Ainaži, the tree growth in height till the age of 30-40 years was considerably faster than in other sites, showing a relatively strong downward trend at older ages. On the other hand, at Rundāle, at young age the tree growth in height was slower, yet maintaining steady growth rates later.

A visual comparison of the height-age curves modelled in this study with those derived from the growth and yield tables is presented in Fig. 3. The tree growth in height for the stands with Orlov's site index I (Viesīte and Barkava) and those of site index II (Rundāle) quite accurately follow the corresponding growth curves However, at Ainaži it markedly differed from that predicted by the growth and yield tables; before age 30 years the growth in height in this site exceeded that of the site index I curve, showing a decline in 

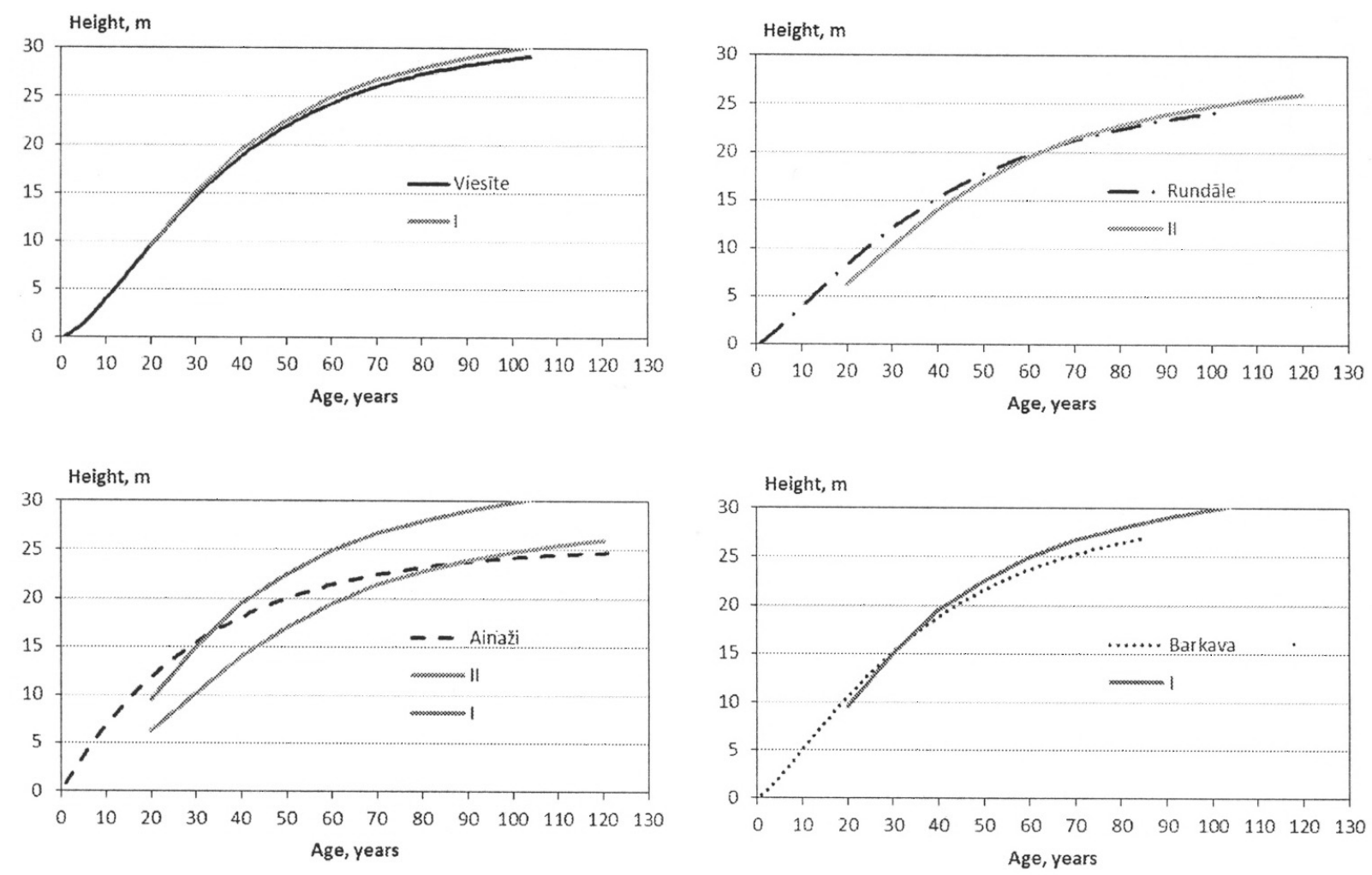

Fig. 3. Modelled height-age curves for tree growth in study sites compared to M. M. Orlov's site index class I and II curves (Sacenieks and Matuzānis, 1964).

subsequent years, and by the age of 90 falling below the table-predicted growth rates for the site index II stands.

For the ash trees analysed, the current annual incremental (CAI) for DBH culminates at a relatively early age, with the

a
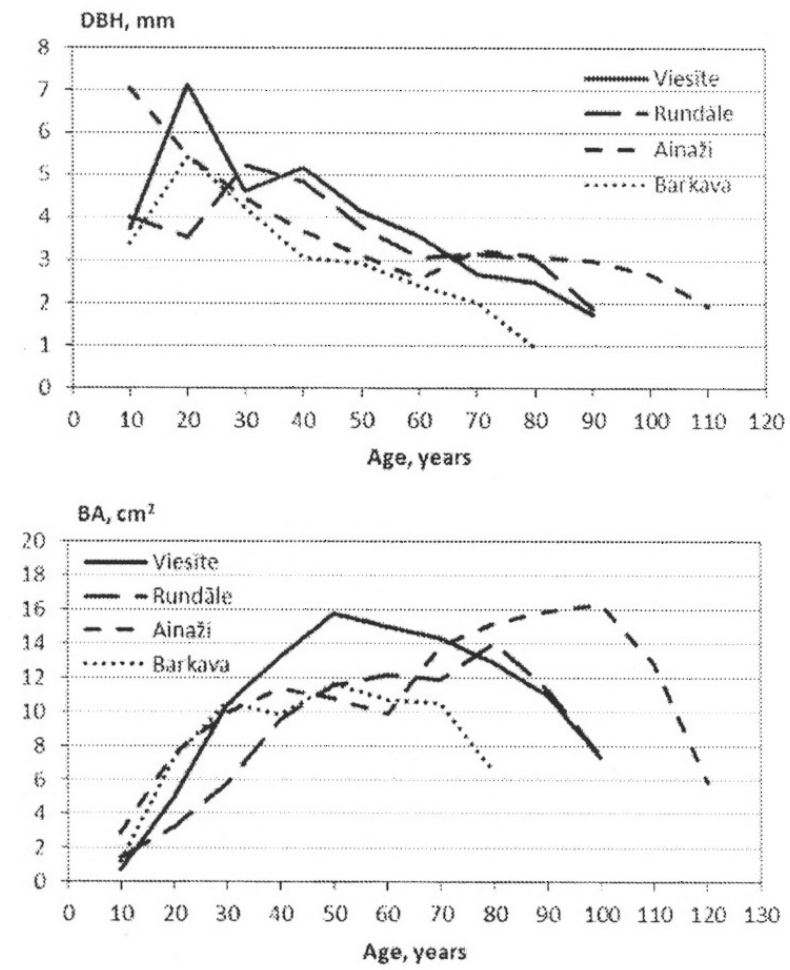

peaks at age 20 years (Viesīte and Barkava) and 30 years (Rundāle), followed by a decline. At Ainaži, the CAI culmination point is even earlier - at the age of 10 (Fig. 4). A similar tendency of early culmination and subsequent decline is observed also for the CAI for tree height.
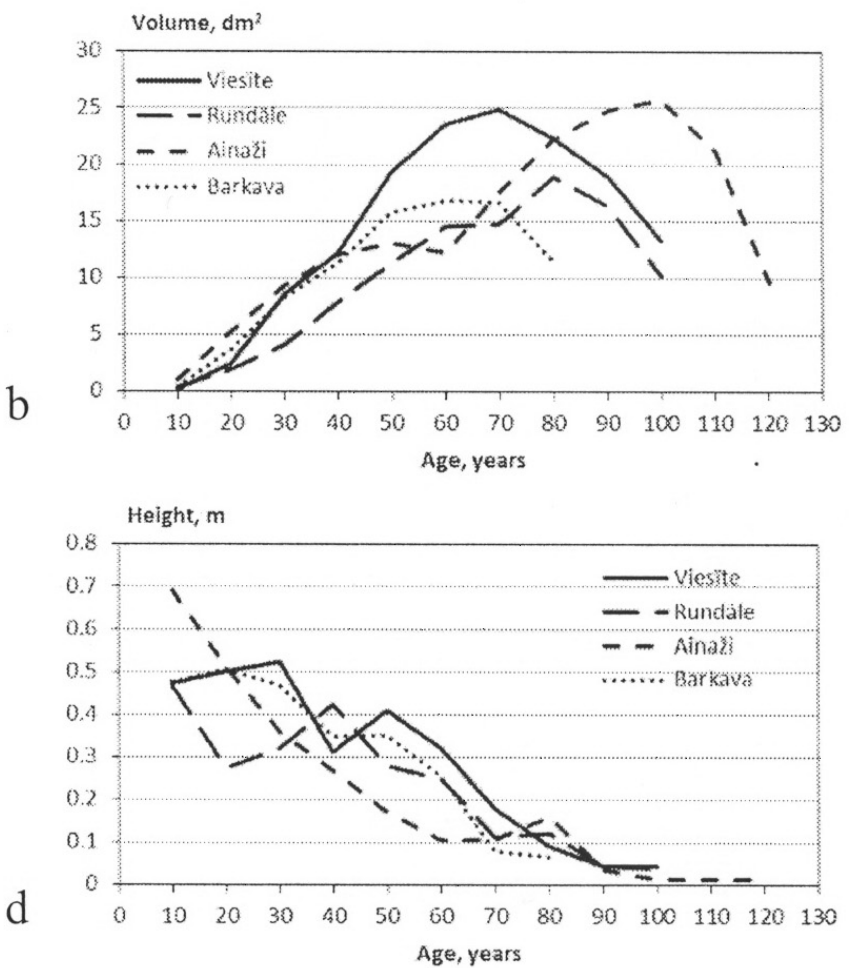

Fig.4. Current annual incremental (CAI) curves of sample trees for (a) DBH, (b) stem volume, (c) basal area, and (d) height. 
For stem volume, the CAI reached a maximum at age 70 to 80 years, except for Ainaži, where continuous volume growth continued till age 100 years. At Ainaži, the CAI for basal area, similar to that for volume, was stable for a few more decades than in the other sites.

We also found high variation in juvenile growth rates for ash. Five of the studies twelve trees reached height $1.3 \mathrm{~m}$ $(\mathrm{DBH})$ already in the second year of growth, while for others this required several years; one sample tree reached the this height at only age seven years. It is typical that the differences in juvenile growth were found for trees growing on the same site. At Rundāle, for example, the trees reached height $1.3 \mathrm{~m}$ in the second, third and even seventh year of growth.

Common ash is found in mixed forests throughout Latvia, with monoculture stands concentrated mainly in specific regions (Fig. 5). The highest proportion of common ash is in the central part of Latvia. However, the concentration of ash-dominated forests is also quite high in a number of other regions in the south-west, north-east, and south-east of the country. According to the physiographic zoning of Latvia by Ramans and Zelčs (1995), the ash stands are found mostly in uplands. In the western part of the country the highest proportion of ash is in the Rietumkursa, Ziemel,kursa and Austrumkursa uplands; in the eastern part — in the Vidzeme, Idumeja, Augšzeme and Latgale uplands. Furthermore, localities with a fairly high concentration of common ash are in the Zemgale Plain in the central part of Latvia, and in the northern part of costal lowland.

\section{DISCUSSION}

In recent decades there have been few internationally known studies on the growth patterns of common ash in the
Baltic Sea region. In a study by Kadunc (2004) on the growth and yield of common ash in Slovenia, the CAI for height most often peaked before the tree reached 10 years, with the highest CAI for diameter falling between ages 11 and 30 years. In general, the results of the present study confirm that height and diameter growth peaks of ash occur at a relatively early age. However, an analysis of the tree growth done in this study indicate considerable differences: at Ainaži the ash trees show a distinct growth rhythm, where the CAI for height peaked at the age of 10 years, followed by another peak at the age of 50 . The same also occurred for the peak of CAI for volume at an advanced age.

A variety of factors may affect the growth in height of young trees. In Latvia, the young ash shoots may heavily suffer from late spring frosts, stunting their growth in height in the current year (Sakss, 1958). The growth of ash saplings depends also on the regeneration method used for the particular site. In the mid-20th century, it was recommended that natural regeneration by ash in clear-cuts should be facilitated by removing the advanced growth of ash and understory to stimulate growth of new shoots rather than retaining advance growth. The stump shoots of ash grow very fast and quickly overcome the critical height at which they are most susceptible to spring frosts and wildlife damage, thus ensuring a better regeneration regime compared to retaining the advance growth (Sakss, 1950; 1958).

The height-age curves derived here show in general a good fit with the site index curves derived from the yield tables, except for Ainaži. The currently used site index curves for growth estimates for ash appear to somewhat underestimate the juvenile height growth and accordingly overestimate that of mature trees.

At Ainaži, a variety of factors may affect the growth patterns and growth rates of ash stands: specific habitat condi-

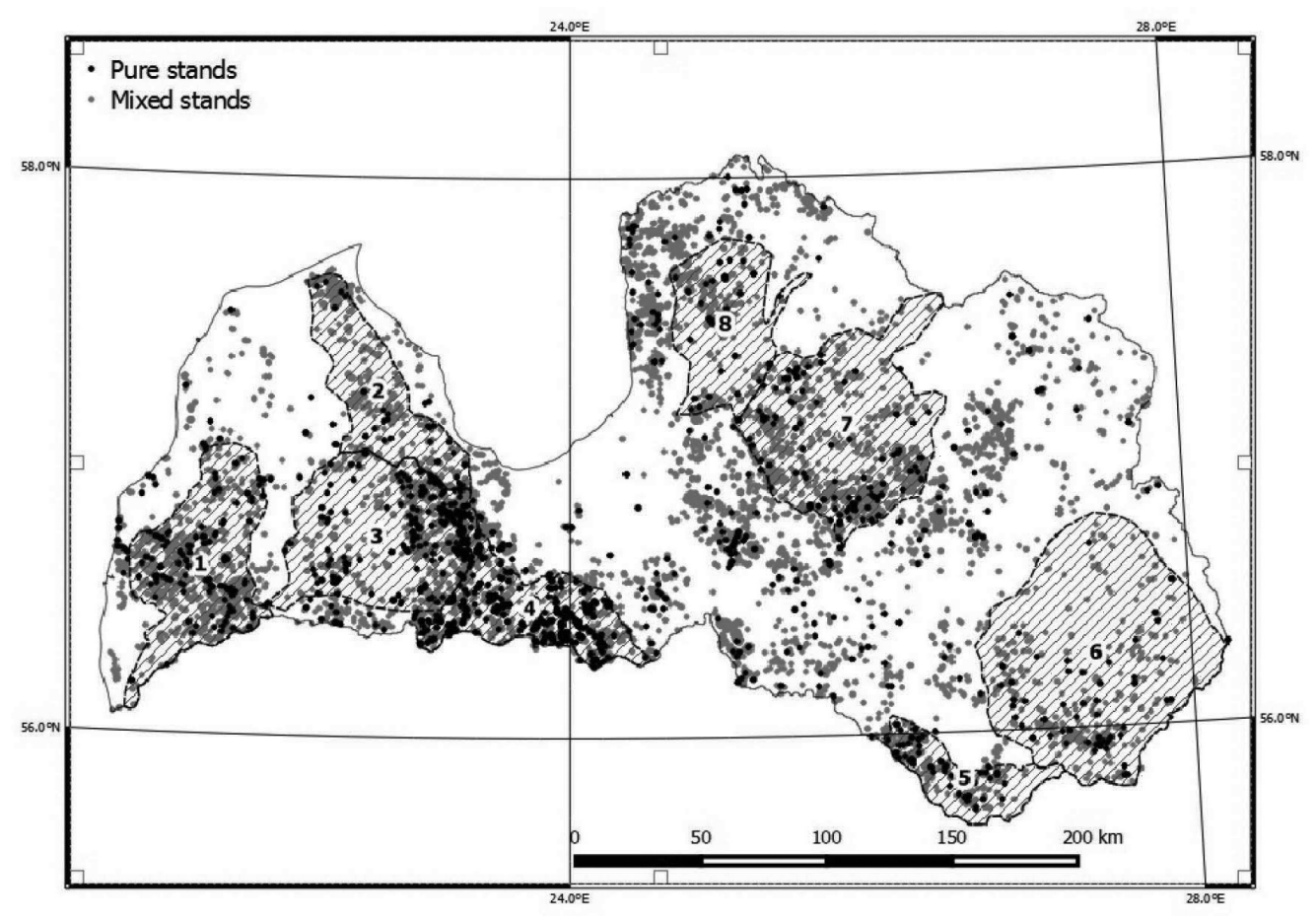

Fig. 5. Spatial distribution of common ash stands in Latvia. Physiographic regions of Latvia marked with transverse lines: 1, Rietumkursa Upland; 2, Ziemeḷkursa Upland; 3, Austrumkursa Upland; 4, Zemgale Plain; 5, Augšzeme Upland; 6, Latgale Upland; 7, Vidzeme Upland, Idumeja Upland. 
tions, population effect, as well as the management practices applied. It is well known that thinning can markedly promote stand growth, especially if carried out at young age (Juodvalkis et al., 2005). The records about the origin and previous management of the respective stands are not known. It appears that there is a need for more in-depth studies to determine if at Ainaži the peculiar growth patterns of ash are site-conditioned, or due to population or community features.

This study also allows to estimate changes in natural occurrence of common ash over the territory of Latvia during the second half of the 20th century. Compared to the ash distribution map produced by Sakss (1958) (Fig. 1), the ash stands have spread over wider territories, especially in the middle part of eastern Latvia (Fig. 5). Marigo et al. (2000) that an increase in common ash populations in Europe resulted from rural depopulation and excluding difficult terrains like steep slopes or waterlogged sites from cultivation. In Latvia, during the past twenty years, vast areas of agricultural lands were abandoned and are now partly overgrown by forest (Liepins et al., 2008). The natural increase of forest areas by overgrowing of abandoned lands in the recent decades seems to be among the reasons for promoting the expansion of ash.

Although common ash is found throughout Latvia, there are regions with a distinct concentration of ash-dominated stands. According to the studies by Sakss (1958), the concentration of common ash stands is the highest in Latvian lowlands, which is still true, for example, in the Zemgale Plain of the central part of Latvia. This area is a part of the Lielupe basin, known for its rich clayey soils and wellbranched network of natural watercourses, which ensure a good drainage over most of the territory, providing good conditions for common ash establishment. However, uplands also had relatively high concentration of common ash. Common ash is a site-demanding species, preferring fertile or very fertile, sufficiently moist, yet well-draining soils (Sakss, 1958; Kerr and Cahalan, 2004; Støeğtík and Šamonil, 2006; Dufour and Piégay, 2008; Weber-Blaschke et al., 2008). In the uplands the growth of common ash may be favoured by highly varying hilly relief, where common ash most often occupies wet hollows and watercourse floodplains, which are natural habitats for common ash. However, confirmation of this requires detailed studies of the ecological specialisation of common ash in areas close to the northern distribution limit of this tree species.

\section{REFERENCES}

Anonymous (2005). FRAXIGEN. Ash Species in Europe: Biological Characteristics and Practical Guidelines for Sustainable Use. Oxford Forestry Institute, University of Oxford, UK, $128 \mathrm{pp}$..

Anonymous (2015). Meža statistikas CD [Forest statistics]. Available at: http://www.vmd.gov.lv/valsts-meza-dienests/statiskas-lapas/publikacijasun-statistika/meza-statistikas-cd?nid=1049\#jump (accessed 10 July 2015).
Cleary, M. R., Arhipova, N., Gaitnieks, T., Stenlid, J., Vasaitis, R. (2013). Natural infection of Fraxinus excelsior seeds by Chalara fraxinea. For. Pathol., 43, 83-85.

Dobrowolska, D., Hein, S., Oosterbaan, A., Wagner, S., Clark, J., Skovsgaard, J. P. (2011). A review of European ash (Fraxinus excelsior L.): Implications for silviculture. Forestry, 84,133-148.

Dufour, S., Piégay, H. (2008). Geomorphological controls of Fraxinus excelsior growth and regeneration in floodplain forests. Ecology, 89, 205-215.

Gross, A., Holdenrieder, O., Pautasso, M., Queloz, V., Sieber, T. N. (2014). Hymenoscyphus pseudoalbidus, the causal agent of European ash dieback. Mol. Plant Pathol., 15, 5-21.

Hannouz, S., Collet, R., Butaud, J. C., Bleron, L., Candelier, K. (2015). Mechanical characterization of heat-treated ash wood in relation with structural timber standards. Pro Ligno, 11, 13.

Juodvalkis, A., Kairiukstis, L., Vasiliauskas, R. (2005). Effects of thinning on growth of six tree species in north-temperate forests of Lithuania. Eur. J. For. Res., 124, 187-192.

Kadunc, A. (2004). Growth characteristics of common ash (Fraxinus excelsior L.) in Slovenia. Zbornik Gozdarstva in Lesarstva, 73, 63-88.

Kenigsvalde, K., Arhipova, N., Laiviņš, M., Gaitnieks, T. (2010). Fungus Chalara fraxinea as a causal agent for ash decline in Latvia. Mežzinātne/ Forest Science, 21, 110-120.

Kerr, G. (1995). Silviculture of ash in southern England. Forestry, 68, 63-70.

Kerr, G., Cahalan, C. (2004). A review of site factors affecting the early growth of ash (Fraxinus excelsior L.). Forest Ecol. Manag., 188, 225-234.

Knaggs, G., Xenopoulou, S. (2004). Guide to Irish Hardwoods. COFORD, Dublin. 4 pp.

Lekwadi, S. O., Nemesova, A., Lynch, T., Phillips, H., Hunter, A., Mac Siśrtįin, M. (2012). Site classification and growth models for Sitka spruce plantations in Ireland. For. Ecol. Man., 283, 56-65.

Liepins, K., Lazdins, A., Lazdina, D., Daugaviete, M., Miezite, O. (2008). Naturally afforested agricultural lands in Latvia - assessment of available timber resources and potential productivity. In: 7th International Conference "Environmental Engineering”, Vilnius, Lithuania, May 22-23, Selected Papers, pp. 194-201.

Marigo, G., Peltier, J.-P., Girel, J., Pautou, G. (2000). Success in the demographic expansion of Fraxinus excelsior L. Trees, 15, 1-13.

McKinney, L. V., Nielsen, L. R., Collinge, D. B., Thomsen, I. M., Hansen, J. K. Kjær, E. D. (2014). The ash dieback crisis: Genetic variation in resistance can prove a long-term solution. Plant Pathol., 63, 485-499.

Mitchell, R. J., Beaton, J. K., Bellamy, P. E., Broome, A., Chetcuti, J., Eaton, S., Ellis, C. J., Gimona, A., Harmer, R., Hester, A. J., Hewison, R. L., Hodgetts, N. G., Iason, G. R., Kerr, G., Littlewood, N. A., Newey, S., Potts, J. M., Pozsgai, G., Ray, D., Sim, D. A., Stockan, J. A., Taylor, A. F. S., Woodward, S. (2014). Ash dieback in the UK: A review of the ecological and conservation implications and potential management options. Biol. Conserv., 175, 95-109.

Pautasso, M., Aas, G., Queloz, V., Holdenrieder, O. (2013). European ash (Fraxinus excelsior) dieback - a conservation biology challenge. Biol. Conserv., 158, 37-49.

Pliūra, A., Heuertz, M. (2003). EUFORGEN. Technical Guidelines for genetic conservation and use for common ash (Fraxinus excelsior). International Plant Genetic Resources Institute, Rome. 6 pp.

Rajora, O. P., Mosseler, A. (2001). Challenges and opportunities for conservation of forest genetic resources. Euphytica, 118, 197-212.

Ramans, K., Zelčs, V. (1995). Fizioǵeogrāfiskā rajonēšana [Physiogeographic districts]. Kavacs, G. (ed.). In: Latvijas daba [The Encyclopedia of Latvia's Nature]. Latvijas Enciklopēdija, Rīga, 74-76 pp. (in Latvian).

Sacenieks, R., Matuzānis, J. (1964). Mežsaimniecības tabulas [Tables for Forestry]. Latvijas Valsts izdevniecība, Rīga. 207 lpp. (in Latvian). 
Sakss, K. (1950). Oša dabiskā atjaunošanās jauktās audzēs Latvijas PSR [Natural regeneration of common ash in mixed stands in the Latvian SSR]. LPSR ZA Mežsaimniec. probl. instit. raksti, 2, 5-34 (in Latvian).

Sakss, K. (1958). Oša mežaudzes un to atjaunošanas pamati [Common Ash Stands and Its Regeneration Basics]. Latvijas Valsts izdevniecība, Rīga. 131 pp. (in Latvian).

Sakss, K. (1952). Oša mežeņu un celmiņu stādījumu izmēg̣inājumi [Planting common ash with wildings and small stumps]. LPSR ZA Mežsaimniec. probl. inst. raksti, 4, 3-29 (in Latvian).

Received 17 February 2016
Střeštík, S., Šamonil, P. (2006). Ecological valence of expanding European ash (Fraxinus excelsior L.) in the Bohemian Karst (Czech Republic). J. For. Sci., 52, 293-305.

Wardle, P. (1961). Fraxinus Excelsior L. J. Ecol., 49, 739-751.

Weber-Blaschke, G., Heitz, R., Blaschke, M. and Ammer, C. (2008). Growth and nutrition of young European ash (Fraxinus excelsior L.) and sycamore maple (Acer pseudoplatanus L.) on sites with different nutrient and water statuses. Eur. J. For. Res., 127, 465-479.

Zālītis, P., Jansons, J. (2013). Latvijas meža tipologija un tās sākotne [Latvian Forest Typology and Its Origin]. DU Akadēmiskais apgāds "Saule", Daugavpils. 167 pp. (in Latvian).

\section{PARASTĀ OŠA (FRAXINUS EXCELSIOR L.) MEŽAUDŽU AUGŠANAS GAITA UN TELPISKĀ IZPLATİBA LATVIJĀ}

Parastais osis ir izplatīts visā Latvijas teritorijā kā piemistrojuma suga, tomēr, piemērotās augtenēs — barības elementiem bagātās, mitrās, bet labi drenētās augsnēs — tas spēj veidot arī ekoloǵiski stabilas tîraudzes. Pēdējās divās dekādēs ošu audžu bojāeja ir kḷuvusi par nozīmīgu problēmu visā Eiropā; ošu audžu kalšanu izraisošais patogēns ir identificēts arī Latvijā. Pētījuma mērkis ir skaidrot ošu augšanas gaitas savdabības dažādās šīs sugas populācijās Latvijā, kā arī veikt ošu audžu telpisko izvērtējumu, identificējot reǵionus, kuros šĩs sugas mežaudzes koncentrējušās. Mūsu pētījums atklāja, ka oša juvenilā augšanas gaita var būt ḷoti atškirīga, un apstiprināja, ka koku augstuma un caurmēra augšanas kulminācija notiek salīdzinoši agrā vecumā. Mūsu dati norāda uz to, ka pēdējo piecdesmit gadu laikā ošu audžu izplatība Latvijas teritorijā ir ievērojami palielinājusies, visdrīzāk — bijušo lauksaimniecības zemju apmežošanās rezultātā. Ja neskaita Zemgales līdzenumu, šobrīd lielākā ošu mežaudžu koncentrēšanās vērojama augstienēs — platībās ar daudzveidīgu reljefu. 